\title{
THE HISTORY OF EMERGENCE OF SUGHD CITIES
}

\author{
Isamiddinov Muhammadjon \\ Doctor of Sciense, professor of Department of World History of Fergana State University, Republic of Uzbekistan
}

Article DOI: https://doi.org/10.36713/epra5391

\begin{abstract}
The article examines the history of the emergence of Sughd cities on the basis of archeological sources. In particular, based on the results of recent research on Kuktepa, Uzunqir, Yerkurghan and Afrosiab, their emergence is discussed.
\end{abstract}

KEY WORDS: Sughd, Afrosiab, Yerkurghan, Uzunqir, Yaz-depe.

\section{INTRODUCTION}

When an archeologist was to be asked the question of "How many years has it been since the first emergence of a city in the place of Yerkurghan in the oasis of Karshi?" ten to fifteen years ago, his answer would probably be like «The city was established 2500 years ago». Indeed, when the defense walls of Yerkurghan was first studied in the late $70 \mathrm{~s}$ and early $80 \mathrm{~s}$ of the last century by M.Turebekov, the same result was obtained. Not only the defense walls of Yerkurghan, but all cities of Sughd's defense walls were also studied specifically [10. p. 108]. A number of $\mathrm{PhD}$ dissertations have been done on their history. We are not going to say anything bad about the doctorates of the period, but their mistakes are "forgivable", the main reason for their mistakes was not so advancement of periodization of archeological material - cultural findings and methods of studying ancient sites in the science of archeology.

\section{MATERIAL AND METHODS}

S.P. Tolstov was the first to raise the issue of periodization of the history of Central Asia on the basis of Khorezm materials [8; 9]. In parallel with the same work in Samarkand G.V. Grigorev conducted excavations in the southern part of Samarkand, at the monument of Tali-Barzu. He was very successful in conducting layered excavations for the first time on a monument left over from the soil-related architecture of Central Asia. Indeed, the difference between pottery from different layers was obvious [1;2].

In connection with the chronology of the history of Samarkand by Terenojkin in the 50s of the last century, M.E. Masson also expressed his attitude to this chronology [4]. It was in the 50-60s of the last century that $\mathrm{M}$. Pachos, based on the study of the defensive walls of Afrosiab, wrote that "the city of Samarkand was founded in the VIII century AD" [11].

M. Turebekov, who studied the defensive walls of Sughd, came to the conclusion that "the oldest defensive walls of Yerkurghan are made of big blocks of mud in the shape of brick, the thickness of which is $3 \mathrm{~m}$, it was built in the VI-V centuries BC." Such a solution leads to the conclusion that the cities in the main regions of Central Asia were formed during the Achaemenid Empire. A.I. Terenojkin [6; 7], and G.V. Shishkina [12. p. 20; 13. p. 221-246] who studied the ancient layers and defensive walls of Afrosiab a while ago came to the same conclusion.

Therefore, it was not in vain and spontaneously that a number of great experts came to an agreement. What were the main arguments that "affirmed" their views? We know that the part of the defensive walls found in Afrosiab, which can be called the "defensive walls of the Achaemenid period", was opened in a much larger area. Part of it has also been restored and is still visible on the right side of the road from the city to the airport, on the high bank of the Siyab River and the cliff. These defensive walls were indeed Achaemenid-era defensive walls, and right-angled bricks were used to restore the wall, which was built in the form of a corridor-gallery. In the northern part of Afrosiab, the same wall is made of big blocks of mud in the shape of brick, and its general shape is also restored in the form of a corridor-gallery. That is, the soldiers 


\section{EPRA International Journal of Research and Development (IJRD)}

\section{Volume: 5 | Issue: 10 | October $2020 \quad$ - Peer Reviewed Journal}

involved in the defense of the city stood inside the corridor-like defensive wall on the inside of the wall and fired at the enemy outside at right angles to the city defense.

Another major reason why the first defensive walls in Afrosiyab date back to the Achaemenid period is that cylindrical-conical pottery was found in the area of this monument. In the $50 \mathrm{~s}$ and $70 \mathrm{~s}$ of the last century, cylindrical-conical pottery was also found in the stratigraphic excavation discovered by V.M. Masson at the Yaz-depe monument in the territory of southern Turkmenistan [5]. These successive archeological complexes have been recognized by many archaeologists as the main base monuments almost to the present day, and when similar pottery were found, they were periodized as they date back to the VI-IV centuries BC. Of course, the Yaz-depe monument consists of three successive archeological complexes, the lowest layers of which belong to the Early Iron Age, the other two layers date back to the VIII-VII centuries BC, and the upper layer to the VI-IV centuries BC. Since Afrosiab also had such pottery, the period of the city's emergence was also peridized as to date back to this period.

We are convinced that if such problems in the emergence of ancient cities had not been achieved in 1990-91 by the joint Uzbek-French expedition to Afrosiab, our idea of the emergence of Sughd cities of Koktepa, Uzunqir, Erkurgan, including Afrosiab itself, would have been completely different. The fact is that in the process of excavating the first defensive wall of Afrosiab in 1990-91, a monolithic raised defensive wall was found in the lower layers of the above-mentioned corridor-gallery-type defensive wall, i.e., under the round shaped bricks. This wall differed from the previously known walls not only in the brick used for it, but also in the shape of the wall, in other words, it was built in a monolithic style with thickness of 7-8 meters. During the construction of the wall, it was raised as separate blocks (parts). A 220-hectare area of the city was surrounded by a similar wall. In addition, the acropolis part of the city, in other words, the arched part, was also separated. The bottom of the city governor's castle also rose with the same rounded bricks. So, these newly discovered defensive walls were radically and fundamentally different from the defensive walls that were previously considered to be the "defensive walls of the Achaemenid period". Because the bricks are not rectangular, but rounded, the shape of the wall is not in the form of a corridor-gallery, but in a monolithic style, with a thickness of 7-8 meters [3].

After the discovery of these defensive walls in Afrosiyab, archaeologists remembered that there was a similar monument in Koktepa, $35 \mathrm{~km}$ north of Samarkand, made of rounded bricks, and visited the monument. However, not all members of the expedition believed that Koktepa was a very ancient monument. As a result, international expeditions were conducted here only after the author of these lines spent two years clearing various sections of Koktepa and determined that the monument belonged to the Early Iron Age trough precise facts. As a result of the research, 2-3-meter layers were discovered in Koktepa in the Zarafshan oasis, indicating that the first Iron Age peasant communities lived, which was not known for anybody up until then, in basements and semi-basements. In everyday life, these people used stone knives, sickles and handmade pottery with a red pattern on it.

It was known that the population with such a culture was widespread in the main agricultural oases of Central Asia in the XII-VIII centuries BC.

In Koktepa it is possible to see that the owners of the above culture learned to build monumental buildings from rounded bricks from the VIII century BC. Two of these monumental buildings were erected in the Koktepa area. One was in the center of Koktepa and was surrounded by a separate wall with the thickness of 2.5 meters. We called the remains of this building a «temple». In the second stage of the development of the monument, a platform made of round bricks of $40 \times 40$ were rose above the ancient temple.

In the south-eastern part of Koktepa there was a "governor's residence" built of the same rounded bricks as above, and it was surrounded by a separate wall about 5 meters thick. In the corner of the palace there was also a "fortress" with a platform measuring $40 \times 40$. When erecting the walls of various buildings, they used a method that was so characteristic that it was suitable for all the cities of Sughd at that time.

This means that both buildings in the Koktepa area were surrounded by separate walls. The outer defensive wall of the monument was also preserved on the west side, and was built of straight rectangular bricks. We think that the time when the outer wall was built must date back to the VII-VI centuries BC, because only one or two round-shaped bricks were found in the section. This external defensive wall surrounded an area of about 100 hectares.

Thus, it was possible to observe the main stages of the process of emergence of the first cities in Koktepa, the structure of the first cities, the main elements of interest to archaeologists, such as construction techniques.

Well, just like the above, the main elements of the city were observed in which cities of Sughd. The earliest was in Afrosiab, where the ruins of this city were erected along with a 'governor's residence', a defensive wall built of the first monolithic rounded bricks occupying an area of 220 hectares. Prior to the construction of this wall, Afrosiyab was surrounded 


\section{EPRA International Journal of Research and Development (IJRD)}

\section{Volume: 5 | Issue: 10 | October $2020 \quad$ - Peer Reviewed Journal}

by a oval-shaped wall that rose in the style of a "lomboz".

The Uzunkir monument is located near the city of Kitab, only a part of its defensive wall, with the length of 70 meters from the ruins of the ancient city survived. Expert scholars who have studied this wall have noted that it was a defensive structure built on the basis of ancient oriental traditions in the VII century BC. Sh. Rakhmonov, who visited the section of the Uzunqir wall 5-6 years ago, told us that there were rounded bricks under this defensive structure.

So, since the earliest development of the major cities in Koktepa, Afrosiab, and Kitab district continued in the same way, why should Yerkurgan's emergence and its development be different?

We have already mentioned that the city was built in the VI-V centuries BC according to the research of various scholars. The fact is that when we excavated in the potter's neighborhood of Yerkurgan in the late 70 s of the last century, it was discovered that only one or two places had layers belonged to the $\mathrm{X}$-VIII centuries $\mathrm{BC}$. Because undergroundwater rose around Yerkurgan which made excavation of the lower layers one of the most difficult issues.

In 1998-1999, in connection with the preparations for the anniversary of the city of Karshi, there was another opportunity to conduct excavations. The first excavations were carried out 20 years ago, and when it was expanded and renovated by another meter, a previously unknown castle wall dating back to the 7th century BC, around 3 meters thick, was found. Since this wall was inside the main defensive wall of the city, it was considered to be the "first internal defensive wall" and this served as one of the main proofs to celebrate the 2700th anniversary of the city of Karshi. This is because the tradition of building cities that surrounded the city and did not have a single defensive wall was typical of the countries of the Ancient East. For example, the Bronze Age monuments of Jarkutan in Surkhandarya, Oltintepa in Turkmenistan, and the Koktepa which belong to the Early Iron Age also had temples and governor's quarters surrounded by separate walls in their early development. In our opinion, Yerkurgan also developed in its early revolution in accordance with the traditions of the Ancient East.

On the occasion of the anniversary of the city of Karshi, the city administration allocated funds for the study of Yerkurgan. As a result, there was an opportunity to conduct additional, new archeological excavations here. In two places of excavations we found the oldest and main defensive wall of the city even under the defensive wall, which was previously unknown to anyone and was previously recognized as "built during the Achaemenid period". This wall was raised to a thickness of about 3 meters with the help of building the construction in the form of a tape with big blocks of mud, and later repaired and strengthened with additional mud on the inside, bringing the thickness of the wall to 7-8 meters.

\section{RESULTS}

The technique of building the fortress wall and the first defensive wall in Yerkurgan is also reminiscent of the technique of building a wall of round bricks of the Sughd cities mentioned above. Although Yerkorgan's wall is tape-like big blocks of mud, its "tapes" are a series of pieces of clay embossed over brown clay, and the next row of "tape" is of course thicker than the mud taken from under the ditch that surrounds the city. . As far as we know, in both Koktepa and Afrosiab, the color of the clay laid on it with round bricks was more of a muddy color.

A little later, in the VI-V centuries $\mathrm{BC}$, when a new wall was built in Yerkurgan, the old wall served as a foundation for it, that is, the new wall rose above the old, repaired wall. Thus, the oldest wall of Karshi was found.

\section{CONCLUSIONS}

In our opinion, the people who restored the above-mentioned cities of Sughd are the Kayans, one of the first ruling dynasties, whose names are mentioned in the "Shohnoma" and preserved in the memory of the people for many years.

\section{REFERENCES}

1. Grigoriev, G.V. (1940). Talli-Barzu settlement. TOVE, vol. II. Leningrad.

2. Grigoriev, G.V. (1946). The city of Talli-Barzu as a monument of pre-Muslim Sogd. KSIIMK, 12. - P. $94-103$.

3. Isamiddinov, M.Kh. (2002). The origins of the urban culture of Samarkand Sogd (problems of interaction of cultural traditions in the era of the Early Iron Age and in the period of antiquity). Tashkent. $-255 \mathrm{p}$.

4. Masson, M.E. (1950). On the periodization of the history and culture of Samarkand. VDI, №. 4, Moscow.

5. Masson, V.M. (1959). Ancient agricultural culture of Margiana. MIA. Issue 73. Moscow. Science. $250 \mathrm{p}$.

6. Terenozhkin, A.I. (1947). Archaeological exploration at the Afrasiab settlement in 1945. KSIIMK. Issue XVII. Moscow. - P. 25 - 40.

7. Terenozhkin, A.I. (1950). Sogd and Chach. Abstract of Cand. diss. KSIIMK. XXXIII. Moscow. - P. 156 $-163$.

8. Tolstov, S.P. (1946). Experience of chronological classification of monuments of ancient and medieval Khorezm. KSIIMK. XIII. Moscow.

9. Tolstov, S.P. (1949). Periodization of the history of Central Asia. KSIIMK, XXVIII. Moscow. 


\section{EPRA International Journal of Research and Development (IJRD)}

10. Turebekov, M. Defensive structures of ancient settlements and cities of Sogd (VII-VI centuries BC - VII century $A D)$.

11. Pachos, M.K. (1967). To the study of the walls of the Afrasiab settlement. - CA, №. 1. Moscow.

12. Shishkina, G.V. (1969). Ancient Samarkand in the light of the stratigraphy of the western regions of Samarkand. Author's abstract. diss. Cand. historical sciences. Tashkent.

13. Shishkina, G.V. (1969). Materials of the first centuries. BC. from excavations in the northwest of Afrasiab. Afrasiab. Issue I. Tashkent. - P. 221 246.

14. Махмудов, О.В. (2017). “Феномен Толедской школьг и три этапа переводов”. Евразийский Союз Ученых. (12-1 (45)). 5-9 [Makhmudov, O.V. (2017). "The phenomenon of the Toledo school and the three stages of translation". Eurasian Union of Scientists. (12-1 (45)). p.p: 5-9 (in Russ)].

15. Махмудов, О.В. (2017). “Феномен Толедской школь и четыре этапа переводов”. Всеобщая история. (3). 14-21 [Makhmudov, O.V. (2017). "The phenomenon of the Toledo school and the four stages of translation”. General History. (3). p.p: 14-21. (in Russ)].

16. Makhmudov, O.V. (2017). "The Toledo School early center of investigation of the works Central Asian scholars in the Europe". Saarbrucken (Germany): Lambert Academic Publishing. p. 193. ISBN: 978-3-330-33405-2.

17. Makhmudov, O. (2017). "Latin translations of the works Abū Bakr ar-Rāzi and their values in development of the modern sciences". History, Problems and Prospects of Development of Modern Civilization. (18). p. p: 534-538.

18. Makhmudov, O.V. (2017). "Some reasons about employees of the translator Domingo Gundisalvo in Toledo School". Austrian Journal of Humanities and Social Sciences. Vol. 1-2. p.p: 3-7. DOI: http://dx.doi.org/10.20534/AJH-17-1.2-3-7

19. Makhmudov, O.V. (2017). "Translations carried out in the Spanish translation centers (On basis of the works of scientists of antiquity and Muslim East)". Asian Journal of Multidimensional Research (AJMR). Vol. 6-2. p.p: 5-20.

20. Mahmudov, O. (2020). "The beginning of the European renaissance". ERPA International Journal of Research and Development. Vol. 5 (7). p.p. 104-108. DOI: https://doi.org/10.36713/epra4787

21. Makhmudov, O. (2020). "The role of the Toledo as a center for the transfer of scientific knowledge of medieval Eastern scientists to Europe". Евразийский Союз Ученых. №. 6-8 (75). p.p. 1316. DOI: 10.31618/ESU.2413-9335.2020.8.75.89

22. Makhmudov, O. (2020). "The Toledo School Early center of translation in Medieval Europe". European Researcher. Series A. Vol. 11 (3). p.p. 150-158. DOI: 10.13187/er.2020.3.159 